\title{
Distribution and healthy status of seagrass bed in Lamongan coastal area
}

\author{
Citra Satrya Utama Dewi ${ }^{1,2^{*}}$, Defri Yona $^{1,3}$, Pratama Diffi Samuel ${ }^{4,5}$, Rizqi Aimmatul \\ Maulidiyah ${ }^{1}$, Ahdiya Syahrir ${ }^{1}$, Yandini Eka Putri $^{1}$, Hilal Rakhmawan ${ }^{1}$, and Maulana Fikri ${ }^{1}$ \\ ${ }^{1}$ Department of Marine Science, FPIK - UB, Malang, Indonesia \\ ${ }^{2}$ Coastal Resilience and Climate Change Adaptation - CORECT Research Group, FPIK - UB, \\ Malang Indonesia \\ ${ }^{3}$ Marine Resource Explore Management - MEXMA Research Group, FPIK - UB, Malang, Indonesia \\ ${ }^{4}$ Department of Aquatic Resources Management, FPIK - UB, Malang, Indonesia \\ ${ }^{5}$ Aquatic Bioflock - Research Group, FPIK - UB, Malang, Indonesia
}

\begin{abstract}
The important role of ecology and the high economic value of a seagrass beds are strongly influenced by its health status. The purposes of this study were to 1 . analyze the distribution, extent and type of seagrass; 2. identify the seagrass covering and density; 3 . analyze the health status of seagrass in the coastal village of Lamongan. This research was conducted in July to August 2019, along the coast of Lamongan Regency. Stages of research conducted include: tracking to determine the distribution and extent of seagrass beds, quadratic transects to determine seagrass covering and density, and analysis of seagrass health status. Lamongan consists of two coastal districts, namely: Paciran (9 coastal villages) and Brondong (9 coastal villages). Of the 18 coastal villages there are three coastal villages that have seagrass beds, namely: Banjarwati $(7.7 \mathrm{Ha})$, Kranji (12 Ha), Tunggul (3.8 Ha), with the same type of Enhalus acoroides, and Thalassia hemprichii only at Kranji village. Seagrass covering in the three villages were $83.7 \%, 15.1 \%$, and $15.1 \%$, while the density values were 160 stands $/ \mathrm{m}^{2}, 172$ stands $/ \mathrm{m}^{2}$, and 185 stands $/ \mathrm{m}^{2}$. The seagrass beds in the study areas were classified as poor $(<30 \%)$ to healthy $(>60 \%)$.
\end{abstract}

\section{Introduction}

Climate change has become an increasingly interesting and discussed issue, because of its impact has been felt directly by humans, including the increasingly hot temperatures. This is caused by increasing greenhouse gases, including carbon dioxide $\left(\mathrm{CO}_{2}\right)$. Many climate change mitigation efforts to reduce gas have been carried out by optimizing the utilization of resources on land and sea. The marine coastal area is known to absorb $\mathrm{CO}_{2}$ and store it in the form of carbon, both as biomass and stored in the substrate, especially in the three key ecosystems, namely mangrove forests, seagrass beds, and coral reefs. More than $50 \%$ of the

\footnotetext{
*Corresponding author: satryacitra@ub.ac.id
} 
world's biological carbon is stored in coastal and marine areas as blue carbon, and is known to absorb and store carbon more effectively than land forests. Reducing the increase of $\mathrm{CO}_{2}$ concentration with natural mechanisms can be done through photosynthesis mechanism of seagrass vegetation $[13,14]$. Moreover, seagrass communities with an area of less than $0.2 \%$ of the world's seas are thought to be able to absorb and store $10 \%$ of carbon in the ocean . Seagrass meadows in Indonesia is $30000 \mathrm{~km}^{2}$ consisting of thirteen species is one of the widest in the world $[15,16]$. The potential of carbon storage in seagrass meadows is $2-4$ times greater $\left(4 \mathrm{t} \mathrm{C} \mathrm{ha}^{-1} \mathrm{yr}^{-1}\right)$ than that in the tropical forest $\left(1.8-2.7 \mathrm{t} \mathrm{C} \mathrm{ha}^{-1} \mathrm{yr}^{-1}\right)[17,18,19]$. However, coastal and marine environmental services as blue carbon are very dependent on the health of the ecosystems in them.

Lamongan Regency is part of the "Gerbangkertosusila National Strategic Area" which is certain to have large human and industrial activities, the consequence of which is more $\mathrm{CO}_{2}$ gas production compared to other regions. From another perspective, this district is also known to have seagrass community structures in its coastal areas and is thought to have the potential to absorb carbon from the atmosphere, so that it can be one of the solutions to climate change mitigation. The purposes of this study are to (1) analyze thedistribution, extent and type of seagrass; (2) identify the seagrass covering and density; and (3) analyze the health status of seagrass in the coastal village ofLamongan. Visualization of seagrass community health data generated from this study, can be used for analysis of coastal and marine protected areas. The results of the analysis and visualization can be used in the preparation of the management plan for seagrass communities as coastal and marine protected areas for climate change mitigation.

\section{Methodology}

This research was conducted in July - August 2019, in the Coastal Region of Lamongan Regency and Laboratories in University of Brawijaya. This research consists of several stages, namely preparation, data collection, and data analysis. Data collected from the study area included seagrass distribution and species, substrate type, seagrass percent cover, and seagrass density.

Preleminary study on this study was started by conducting a quick survey of seagrass distribution along the coastline of Lamongan Regency, using a tracking method with the help of tools such as GPS, Underwater Cameras, and Basic Diving Equipment. Next, the data collection of substrate type, seagrass percent cover, and density of seagrass species was carried out using the Line Intercept Transect method combined with Quadrant Transect (Fig.1), this method refers to Seagrass Watch [2] which also adopted in some studies [3,4].

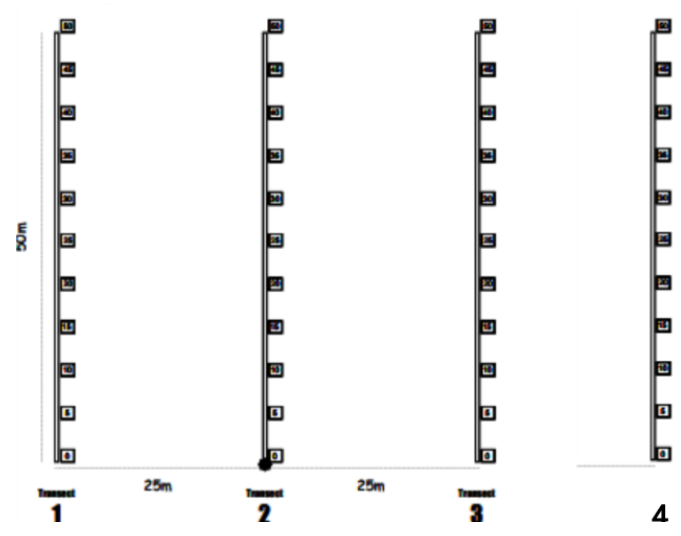


Fig. 1. Visualization of the Line Intercept Transect Method combined with the Quadrant Transect

Identification of seagrass species was done by using some literatures [5,6]. Data analysis conducted in this study included analysis of seagrass density, seagrass percent cover, and health status of seagrass ecosystem. Data analysis of seagrass species density and seagrass species percent cover was carried out with reference to [3], while seagrass ecosystem health analysis referred to [7], as in Table $\mathbf{1 .}$

Table 1. Status of seagrass based on its percent cover

\begin{tabular}{cc}
\hline Cover $(\mathbf{\%})$ & Status \\
$>60 \%$ & Healthy \\
$30-59,9 \%$ & Less Healthy \\
$<29,9 \%$ & Poor \\
\hline
\end{tabular}

\section{Result \& Discussion}

Lamongan Regency has 2 coastal districts and 18 coastal villages directly adjacent to the coastline [8]. A quick survey conducted at the beginning of this study showed that three of the 18 villages had seagrass communities. The three villages are within the administrative area of Paciran district, namely Tunggul, Kranji and Banjarwati. The seagrass community found was patchy, but widespread. The area of seagrass communities in the villages of Tunggul, Kranji and Banjarwati respectively: $3.8 \mathrm{Ha}, 12 \mathrm{Ha}$ and $7.7 \mathrm{Ha}$ (Fig. 2). The existence of the seagrass community is the only one on the main land of the Gerbangkertosusilo National Strategic Zone.

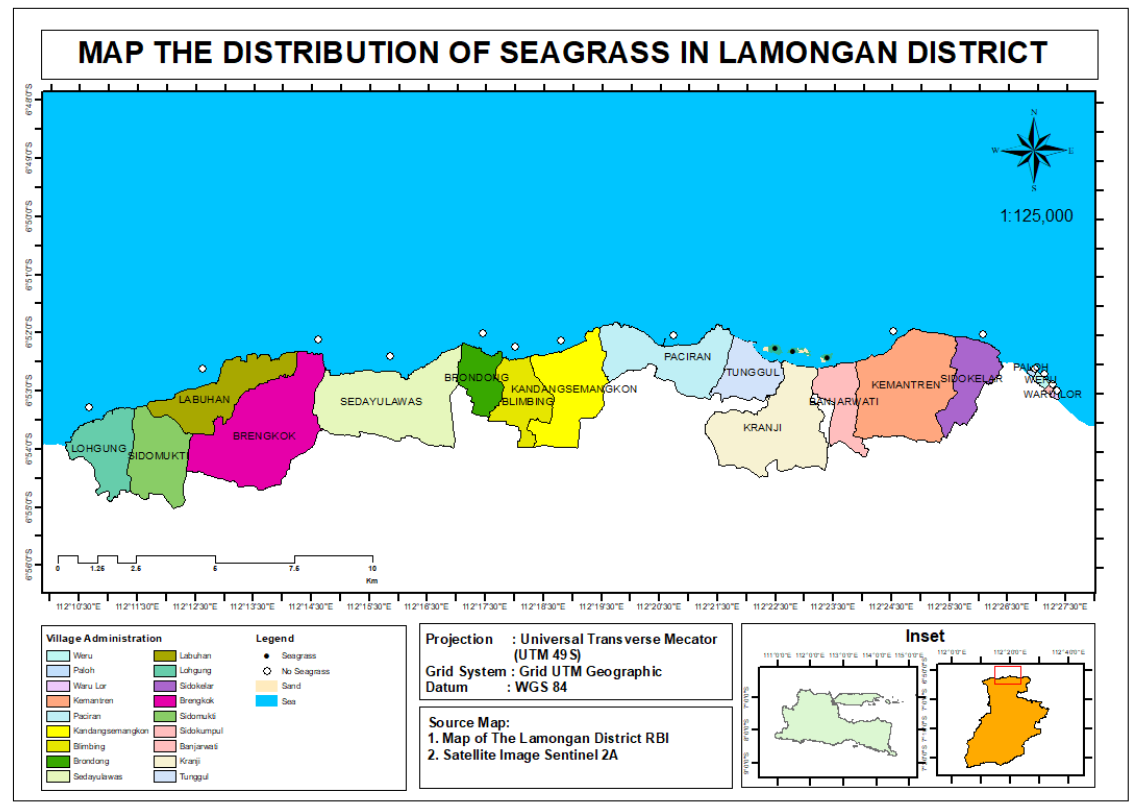

Fig. 2. Distribution of Seagrass in Lamongan District

The variety of seagrass species in Lamongan Regency consisted of only two types, namely Enhalus acoroides and Thalassia hemprichii (Fig. 3). Both of these species are 
seagrass species which have a high frequency of discovery in Indonesia, although they are not included as pioneer seagrass species [9]. When compared to the nearest location, in Bawean Island, Gresik Regency, the diversity of species in the study location is relatively low, only around 30\% (Table 2).

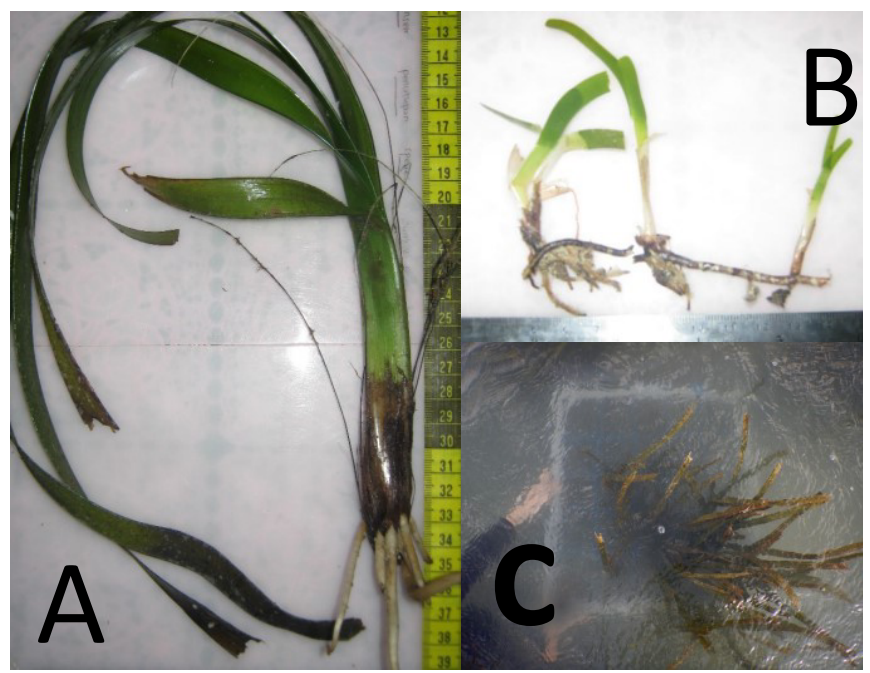

Fig.3. Seagrass on the Coast of Lamongan Regency; (A) Enhalus acoroides; (B) Thalassia hemprichii; (C) Seagrass communities found in one of the quadrant transects.

Table 2. Diversity of seagrass species in the Lamongan Coast of East Java

\begin{tabular}{|c|c|c|c|c|}
\hline No & Species & Indonesia $^{1}$ & $\begin{array}{l}\text { Bawean } \\
\text { Island, } \\
\text { Gresik East } \\
\text { Java }^{2}\end{array}$ & $\begin{array}{l}\text { Lamongan, } \\
\text { East Java }^{3}\end{array}$ \\
\hline & Famili Hydrocharitaceae & & & \\
\hline 1 & Enhalus acoroides & $*$ & $*$ & $*$ \\
\hline 2 & Halophila decipiens & $*$ & - & - \\
\hline 3 & Halophila minor & $*$ & - & - \\
\hline 4 & Halophila ovalis & $*$ & $*$ & - \\
\hline 5 & Halophila spinulosa & $*$ & - & - \\
\hline \multirow[t]{2}{*}{6} & Thalassia hemprichii & $*$ & $*$ & $*$ \\
\hline & Family Cymodocaceae & & & \\
\hline 7 & Cymodocea rotundata & $*$ & $*$ & - \\
\hline 8 & Cymodocea serrulata & $*$ & $*$ & - \\
\hline 9 & Halodule pinifolia & $*$ & - & - \\
\hline 10 & Halodule uninervis & $*$ & $*$ & - \\
\hline 11 & Syringodium isoetifoilum & $*$ & - & - \\
\hline
\end{tabular}




\section{Jumlah Jenis}

12

6

2

*) Found; -) Not Found

1) $\left.[10] ;{ }^{2}\right)[1] ;^{3}$ ) Study result

Seagrass density and percent cover at the study site can be seen in Fig. 4. The highest total seagrass density was found in Banjarwati Village, then Kranji Village, and the lowest in Tunggul Village. The lowest seagrass percent cover was found in the villages of Banjarwati and Kranji, while the highest was in the village of Tunggul. Total seagrass density and percent cover values at the three study sites indicated non-linear conditions. This is caused by 2 factors, scilicet: (1) Morphology of each type of seagrass found at each location; and (2) Seagrass distribution patterns in each study location. The seagrass morphology of $E$. acoroides is bigger than $T$. hemprichii, so the percent cover of each stand is also greater. The pattern of seagrass distribution in Tunggul Village is concentrated at one point, forming monospecies seagrass beds of E. acoroides with an area of $3.8 \mathrm{Ha}$, so that the percent cover value is high. Meanwhile, the seagrass communities in Kranji and Banjarwati consist of two types, spreading to form patches with an area of 12 and 7.7 hectares, so that the percent cover value is lower.

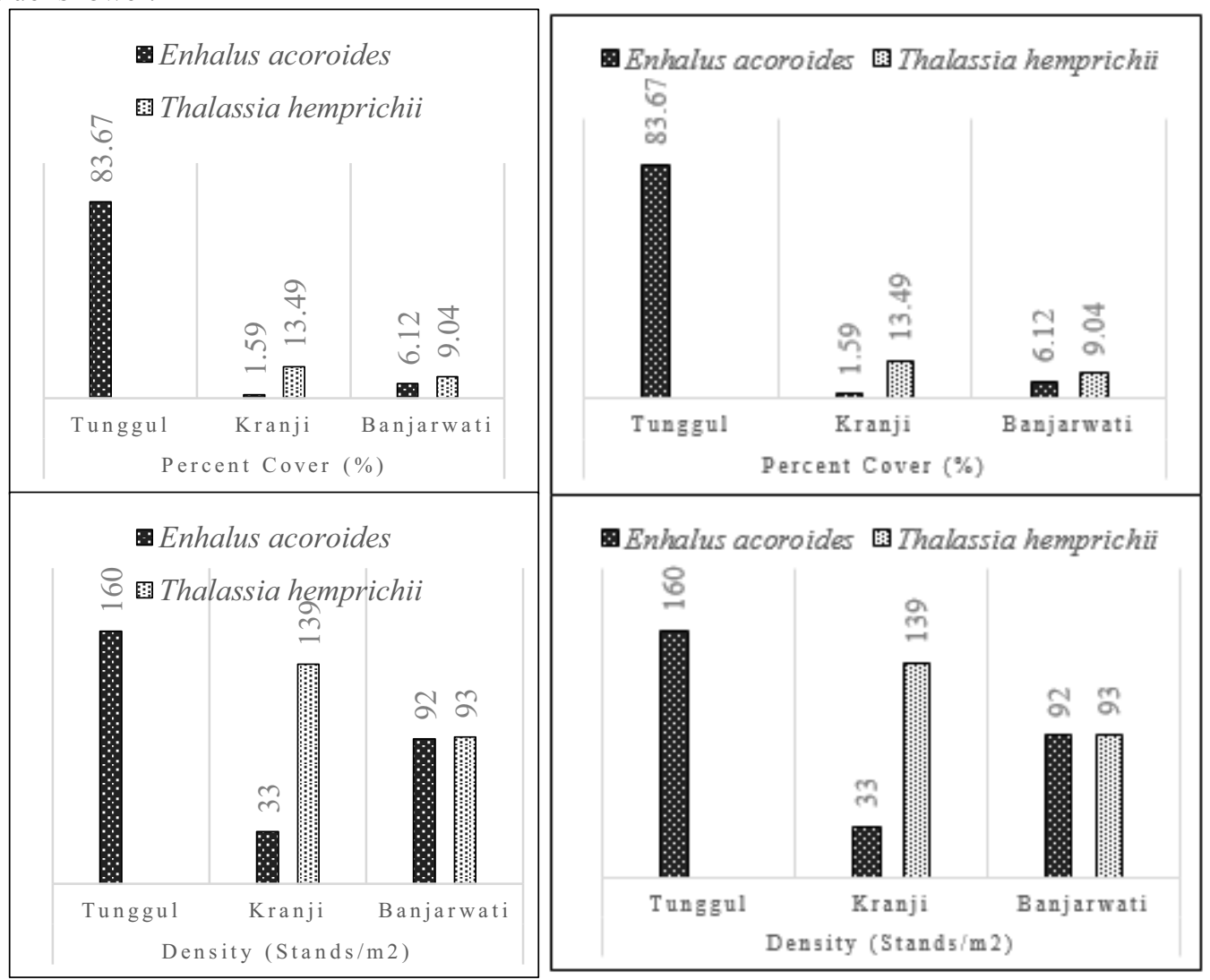

Fig.4. Percent cover (\%) and density $\left(\right.$ stands $\left./ \mathrm{m}^{2}\right)$ of seagrass in Lamongan Regency

The three villages where this study was located where seagrass communities were found have a substrate type of muddy sand to sand, so it is very natural that the seagrass found is a type of E. acoroides and T. hemprichii. E. acoroides and T. hemprichii will grow well on sand substrate type with a combination of mud [6]. Seagrass communities cannot be found 
in other coastal villages, allegedly due to excessive anthropogenic activity, such as reclamation for ports and tourism. A research reported that the threats often faced by seagrass communities were destructive anthropogenic activities, including: ship anchors, reclamation, and plastic waste [2].

The health status of seagrass community was analyzed through percent cover data obtained from the study, referring to the LIPI Coremap [7]. The total percent cover value of seagrasses in Tunggul, Kranji, and Banjarwati villages respectively showed healthy seagrass health status $(83.7 \%)$, poor $(15.1 \%)$, and poor $(15.1 \%)$. Seagrass health conditions in this study site may not be good, but the presence of seagrass communities in this area is a potential ecological resource that is important to be maintained and preserved.

\section{Conclusion \& Recommendation}

This study shows that the seagrass community in Lamongan Regency was only found in three villages, namely Tunggul, Kranji, and Banjarwati, and the seagrass species found were Enhalus acoroides and Thalassia hemprichii. Seagrass percent cover in the three villages in sequence was $83.7 \% ; 15.1 \%$; and $15.1 \%$, while the density value is 160 stands $/ \mathrm{m}^{2}, 172$ stands $/ \mathrm{m}^{2}$, and 185 stands $/ \mathrm{m}^{2}$. Referring to the percent cover value of seagrass communities above, the status of seagrass communities in the three villages is healthy, poor, and poor.

Suggestions that can be submitted in this research are to continue the study to find out the seagrass community's ability to store carbon, so it can inform the added value and ecological role of the community. Although the health condition is not good, this seagrass community is the best along the north coast of the Gerbangkertosusilo, so it is highly recommended to be preserved.

\section{Acknowledgement}

This research can be carried out with funding from the LPPM Beginner Researcher Grant University of Brawijaya in the 2019 Budget.

\section{References}

1. P. I. Macreadie, P. H. York, C. D. H. Shreman, N. J. Keough, D. J. Ross, A. M. Ricart, T. M. Smith, Mar Biol 161, 2939-2944 (2015)

2. L. J. McKenzie, S. J. Campbell, Seagrass-Watch: Manual for Community (citizen) Monitoring of Seagrass Habitat. Western Pacific Edition (QFS, NFC, Cairns) 43pp. (2002)

3. Sukandar, C. S. U. Dewi, Depik, 6(2), 138-145 (2017)

4. C. S. U. Dewi, B. Subhan, D. Arafat, Depik, 6(2), 122-127 (2017)

5. M. H. Azkab, Oseana, 24(1), 1-16 (1999)

6. M. Waycott, K. Mcmahoon, J. Mellors, A. Calladine, D. Kleine, A Guide Tropical Seagrasses of The Indo-West Pacific, Townsville: James Cook University (2004)

7. N. D. M. Sjafrie, U. E. Hernawan, B. Prayudha, I. H. Supriyadi, M. Y. Iswari, Status Padang Lamun Di Indonesia 2018, 2nd Ed, 2. Pusat Penelitian Oseanografi Lembaga Ilmu Pengetahuan Indonesia (2018)

8. Sukandar, C. J. Harshindi, M. Handayani, C. S. U. Dewi, A. W. Maulana, A. Supriyadi, Bahroni, Profil Desa Pesisir Provinsi Jawa Timur Volume 1 (Utara Jawa Timur), 
Bidang Kelautan, Pesisir, dan Pengawasan Dinas Kelautan Dan Perikanan Provinsi Jawa Timur (2017)

9. Den Hartog, C. J. Kuo, Taxonomy and Biogeography of Seagrasses. Di dalam: Larkum AWD, Orth RJ, Duarte CM, editor. Seagrasses: Biology, Ecology and Conservation. Netherlands: Springer (2006)

10. T. Tomasci, A. J. Mah, A. Nontji, M. K. Moosa, The Ecology of The Indonesian Seas. Part Ii. Chapter 13-23. Periplus Edition (Hk) Ltd (1997)

11. C. S. U. Dewi, Sukandar, C. J. Harindhi, Karang dan Ikan Terumbu Pulau Bawean, UB Press (2018)

12. C. S. U. Dewi, B. Subhan, D. Arafat, Sukandar, Journal of Fisheries and Marine Science, 2(2), 128-136 (2018)

13. E. Sunquist, R. Burruss, S. Fulkner, R. Gleason, J. Harden, Y. Kharaka, L. Tieszen, M. Weldrop, Carbon Sequestration To Mitigate Climate Change, Washington DC: United States Geological Survey (2008)

14. G. Bala, Can Planting New Trees Help To Reduce Global Warming? Curr Sci 106(12), 1623-1624 (2014)

15. K. Romimohtarto, S. Juwana, Marine Biology: Science Of Marine Biota. Pusat Penelitian dan Pengembangan Oseanologi, Jakarta: Lembaga Ilmu Pengetahuan Indonesia (1999)

16. E. P. Green, F. T. Short, World Atlas Of Seagrasses, USA: University of California Press (2013)

17. S. L. Lewis, G. L. Gonzalez, B. Sonke, K. A. Baffoe, T. R. Baker, L. O. Ojo, O. L. Philips, J. M. Reitsma, L. White, J. A. Comiskey, M. N. Djuikou, C. E. N. Ewango, T. R. Feldausch, A. C. Hamilton, M. Gloor, T. Hart, A. Hladik, J. Lloyd, J. C. Lovett, J. R. Makana, Y. Malhi, F. M. Mbago, H. J. Ndangalasi, J. Peacock, K. S. H. Peh, D. Sheil, T. Sunderland, M. D. Swaine, J. Taplin, D. Taylor, C. D. Thomas, R. Votere, H. Woll. Increasing carbon storage in intact African tropical forests. Nature 457(7232), 1003-1007 (2009)

18. H. Kennedy, J. Beggins, C. M. Duarte, J. W. Fourqurean, M. Holmer, N. Marbà, J. Middleburg. Seagrass Sediments As A Global Carbon Sink: Isotopic Constrain. Global Biogeochem 24, 1-8 (2010)

19. B. C. Murray, L. Pendleton, W. A. Jenkins, S. Sifeet, Green Payments For Blue Carbon: Economic Incentives For Protecting Threatened Coastal Habitats NI R 11-04, Nicholas Institute for Environmental Policy Solutions, UK: Duke University (2011) 